\title{
PROFIL PEMECAHAN MASALAH SISWA DALAM MENYELESAIKAN MASALAH ARITMETIKA SOSIAL DITINJAU DARI GAYA BELAJAR
}

\author{
Liyan Setiyanik ${ }^{1}$, Junarti ${ }^{2}$, Anita Dewi Utami ${ }^{3}$ \\ ${ }^{1,2,3}$ Program Studi Pendidikan Matematika FPMIPA IKIP PGRI Bojonegoro \\ Email: 'liyansetiyanik6@gmail.com, ${ }^{2 j u n a r t i @ i k i p p g r i b o j o n e g o r o . a c . i d}$ \\ 3anita_dewi@ikippgribojonegoro.ac.id
}

\begin{abstract}
ABSTRAK
Penelitian ini bertujuan untuk mendeskripsikan profil pemecahan masalah matematika siswa dalam menyelesaikan masalah aritmetika sosial yang ditinjau dari gaya belajar, dimana subjek terdiri dari 31 siswa dari kelas VII D SMP Negeri 2 Jiken, yang diambil 6 siswa dengan rincian sebagai berikut yaitu 2 siswa dengan gaya belajar visual, 2 siswa dengan gaya belajar audiotorial, dan 2 siswa dengan gaya belajar kinestetik. Penelitian ini merupakan penelitian deskriptif kualitatif. Instrumen penelitian terdiri dari angket gaya belajar, tes pemecahan masalah dan wawancara. Teknik analisis data yang dilakukan meliputi reduksi data, penyajian data dan penarikan kesimpulan. Dari hasil tersebut diperoleh deskripsi profil pemecahan masalah siswa pada masalah aritmetika sosial berdasarkan gaya belajar sebagai berikut: (1) siswa visual dapat memahami masalah dengan baik, merencanakan penyelesaian dengan tepat, melaksanakan rencana dengan benar dan memeriksa kembali jawaban yang telah dilakukan. (2) siswa audiotorial memahami masalah dengan membaca keras, tidak melakukan tahap memeriksa kembali karena lebih suka berbicara. (3) siswa kinestetik tidak dapat merencanakan penyelesaian dengan baik sehingga hasil yang diperoleh kurang tepat.
\end{abstract}

Kata kunci : gaya belajar, visual, auditorial, kinestetik, aritmetika sosial

\begin{abstract}
This study aims to describe the profile of students' mathemarical problem solving in solving social arithmetic in terms of learning styles, where the subjects consisted of 31 students from class 7 D SMPN 2 Jiken, taken 6 students in the following details namely 2 studentes with visual learning styles, 2 studentes with audiotory learning styles, and 2 students with kineathetic learning styles. This research was a qualitative descriptive study. The research instrument consisted of learning style questionnaire, problem solving tests, and interviews. The technical data included includes data reductions, data presentation, and conclusion drawing. From this result we obtained a profile description of students' promblem solving on social arithmetic problems based on learning styles as follows: (1) visual students can understand the problem well, plan the settlement correcly, implement the plan correctly and reexamine the answer that has been made. (2) audiotory students understand the problem by reading aloud, do not do the recheck stage because they prefer to talk . (3) kinesthetic students cannot plan a settlement well so that the result obtained is incorrect
\end{abstract}

Keywords: learning style, visual, audiotory, kinesthetic, social arithmetic. 


\section{PENDAHULUAN}

Pendidikan sangat berperan penting untuk perkembangan seorang anak. Manusia sendiri tidak pernah lepas dari proses pendidikan formal maupun non formal. Ada banyak mata pelajaran dalam pendidikan salah satunya adalah matematika. Zaif dkk (2013) mengungkapkan belajar matematika tidak hanya belajar mengenai operasi hitung akan tetapi banyak hal yang mendasari seluruh aktifitas kehidupan masyarakat Indonesia.

Tujuan utama pembelajaran matematika untuk memecahkan masalah, pemecahan masalah dipandang sebagai cara yang dilakukan seseorang untuk menyelesaikan masalah matematis berdasarkan data yang diketahui. Junarti (2018) mengungkapkan masalah matematika dibedakan menjadi dua, yakni masalah rutin dan masalah non-rutin. Masalah rutin dapat diselesaikan dengan rumus dan metode yang dikenal, sedangkan masalah non-rutin adalah masalah yang hasilnya tidak dapat ditebak sebelumnya yang tidak dapat diselesaikan dengan metode yang dikenal. Menurut Polya dalam Mahadiningrum dan Novita (2018) tahapan pemecahan masalah matematika meliputi (1) memahami masalah; (2) membuat rencana penyelesaian; (3) melaksanakan rencana; (4) melihat kembali. Namun pada kenyataanya tidak semua tujuan pembelajaran matematika dalam kelas dapat tercapai. Kesulitan pemecahan masalah yang dialami siswa sering terletak pada soal cerita matematika. Materi aritmetika sosial merupakan cabang aljabar yang disajikan dalam bentuk soal cerita yang tidak lepas dari kehidupan sehari-hari.

Setiap siswa memiliki caranya sendiri dalam bersikap, menerima informasi dan memecahkan masalah. Perbedaan yang dimiliki siswa namun kurang diperhatikan adalah perbedaan gaya belajar. Damanik (2015) mengungkapkan gaya belajar merupakan pendekatan yang dipilih dan diterapkan oleh seseorang sesuai dengan tuntutan belajar, dengan mengadaptasi strategi belajar tertentu, gaya belajar yang paling sesuai dipilih seseorang akan dapat membantunya untu mampu belajar secara produktif.

Terdapat 3 gaya belajar yaitu (1) visual (visual learners): gaya belajar yang menitikberatkan pada penglihatan untuk memahami dan mengingatnya, dengan artian seseorang mampu mempercayai suatu hal kemudian memahaminya, apabila melihat dengan adanya bukti yang nyata. (2) audiotorial (audiotory learners): gaya belajar yang menitikberatkan pada pendengaran untuk mampu memahami dan mengingatnya, dengan artian seseorang harus mendengar dengan jelas kemudian baru bisa mengingat dan paham suatu pembelajaran. (3) kinestetik (kinestetik learners): pada gaya belajar kinestetik seseorang mampu memahami dan menyerap informasi dengan gerakan. Restami dkk (2013) ketiga jenis gaya belajar tersebut mempengaruhi siswa dalam belajar. Pengemasan pembelajaran yang sesuai dengan gaya belajar yang dimiliki siswa dapat mengoptimalkan siswa dalam belajar. Perbedaan yang dapat mengakomodasikan berkembangnya ketiga jenis gaya belajar tersebut secara optimal. Namun perbedaan tersebut kurang diperhatikan sehingga pembelajaran yang diarahkan agar siswa mampu menghafal dan memperoleh hasil belajar yang maksimal, tanpa mengevaluasi kesulitan apa yang dialami siswa dan bagaimana cara memecahkan masalah, padahal kebanyakan siswa kesulitan dalam pemecahan masalah soal cerita.

\section{METODE}

Penelitian yang dilakukan adalah penelitian deskriptif dengan pendekatan kualitatif, Prabowo dan Hariyanto (2013) mengatakan penelitian kualitatif adalah 
penelitian yang menghubungkan ide, presepsi, pendapat kepercayaan orang yang akan diteliti dan semuanya tidak dapat diukur dengan angka. Subjek terdiri dari 31 siswa kelas VII D SMP Negeri 2 Jiken, yang diambil 6 siswa dengan rincian, 2 siswa dengan gaya belajar visual, 2 siswa dengan gaya belajar audiotorial dan 2 siswa dengan gaya belajar kinestetik. Sumber data yang digunakan adalah angket gaya belajar, tes pemecahan masalah dan wawancara terhadap subjek penelitian. Teknik pengumpulan data yang digunakan adalah angket, metode tes, dan wawancara.

Angket dalam penelitian ini adalah angket gaya belajar yang diadopsi dari Safrisnti (2016) dengan jumlah 39 pertanyaan yang terdiri dari 13 soal untuk setiap karakteristik gaya belajar, dengan 5 alternatif jawaban angka yaitu; 1 mewakili jawaban pernah, 2 jawaban hampir tidak pernah, 3 jawaban kadang-kadang, 4 jawaban sering dan 5 untuk jawaban selalu.

Tes yang digunakan merupakan tes pemecahan masalah yang dirancang untuk mengetahui pemecahan masalah aritmetika sosial berdasarkan polya. Utami dkk (2018) menyebutkan tes harus dilengkapi dengan rubrik penilaian. Rubrik penilaian yang digunakan berdasarkan polya.

Wawancara yang digunakan adalah wawancara semi terstuktur dan wawancara mendalam untuk memperoleh data dan menyelidiki secara ilmiah, memperoleh informasi guna menjelaskan suatu situasi kondisi siswa saat melaksanakan pemecahan masalah aritmetika sosial berdasar gaya belajar yang dimiliki dan memperoleh fakta tentang profil pemecahan masalah aritmetika sosial yang dilakukan siswa sehingga data yang diperoleh pada wawancara lengkap dan dapat dijamin keaslianya. Wawancara mendalam ialah proses memperoleh keterangan dari subjek mengenai masalah yang dihadapi sambil bertatap muka, Arfanuddin dkk (2016).

Analisis yang digunakan pada penelitian ini dari hasil angket, hasil tes pemecahan masalah aritmetika sosial, yang digunakan untuk memilih subjek penelitian. Langkah selanjutnya adalah analisis hasil wawancara untuk mendeskripsikan profil pemecahan masalah siswa berdasarkan gaya belajar visual, audiotorial dan kinestetik, dengan kriteria pemecahan masalah menurut polya yaitu, memahami masalah, merencanakan penyelesaian, melaksanakan rencana, memeriksa kembali.

Aziz (2017) mengungkapkan teknik analisis data pada model Miles dan Huberman terdiri dari tiga langkah yaitu mereduksi data, penyajian data, dan penarikan kesimpulan adalah model yang paling umum digunakan dalam analisis data penelitian kualitatif. Reduksi dilakukan dengan merangkum, memilih hal-hal pokok dan memfokuskan pada hal-hal yang penting dari metode yang digunakan dalam pengumpulan data di lapangan.

Penyajian yang digunakan berupa tes hasil pekerjaan siswa, kata-kata yang berhubungan dengan fokus penelitian. Dengan menyajikan data akan memungkinkan untuk penarikan kesimpulan berdasarkan informasi yang dipaparkan secara teroganisasi dan terkategori. Penarikan kesimpulan merupakan hal yang penting, Indrawati (2017) mengungkapkan kesimpulan awal yang dikemukakan masih bersifat sementara dan akan berubah bila tidak ada bukti yang kuat, namun kesimpulan pada tahap awal didukung oleh bukti yang valid dan konsisten maka kesimpulan yang dibuat adalah kesimpulan yang kredibel.

Pengecekan keabsahan temuan menggunakan metode triangulasi sumber dan triangulasi metode. Triangulasi diartikan sebagai teknik pengumpulan data yang bersifat menggabungkan dari berbagai teknik pengumpulan data yang telah ada Sugiyono dalam Mursidik dkk (2015). Triangulasi metode dilakukan dengan membandingkan hasil tes pemecahan masalah dengan wawancara pada satu subjek, 
Gunawan (2015) mengungkapakan triangulasi metode adalah usaha mengecek kebenaran data dengan lebih dari satu pengumpulan data untuk mendapat data yang sama. Triangulasi sumber dilakukan dengan membandingkan subjek satu dan subjek dua pada tipe gaya belajar yang sama. Widodo (2016) mengungkapkan bahwa triangulasi sumber atau yang disebut dengan triangulasi data adalah pengumpulan data dari berbagai sumber data dari pandangan yang berbeda.

\section{HASIL}

Penelitian dilakukan melalui tiga tahap yaitu pendahulan, perencanaan dan pelaksanaan. Tahap pendahuluan dilakukan dengan melakukan konsultasi dengan dosen pembimbing dan guru matematika SMP Negeri 2 Jiken terkait dengan penelitian yang akan dilakukan. Tahap perencaan meliputi penyusunan instrumen penelitian, melakukan validasi instrumen, dan mempersiapkan alat-alat penelitian. Tahap pelaksanaan peneliti membagikan angket gaya belajar untuk mengelompokkan siswa. Hasil angket yang telah dihitung oleh peneliti terdapat 14 siswa visual, 10 siswa audiotorial, 8 siswa kinestetik dan 1 siswa visual-kinestetik. Tahap selanjutnya adalah tes pemecahan masalah dan wawancara.

Data hasil tes pemecahan masalah beserta traskrip wawancara subjek visual dalam memecahkan masalah adalah sebagai berikut.

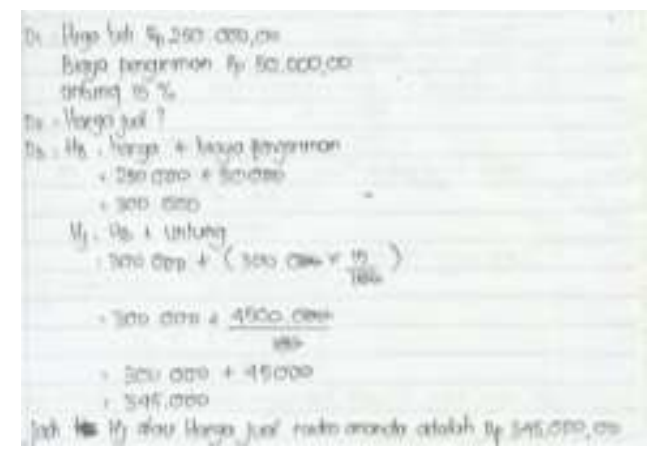

Gambar 1. Hasil Pemecahan Masalah Subjek Visual 1

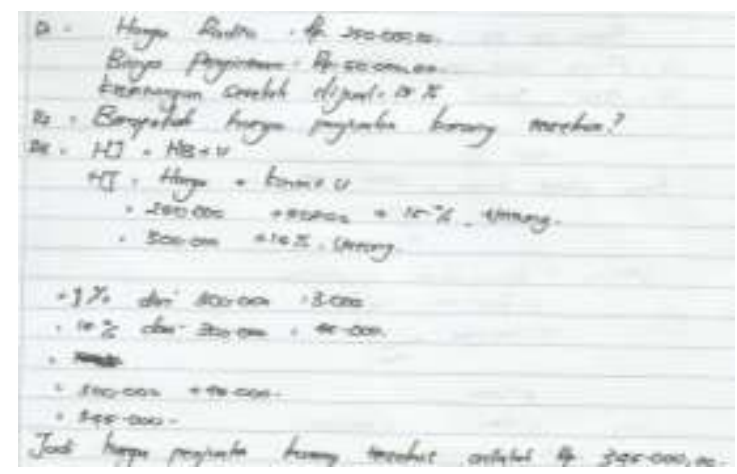

Gambar 2. Hasil Pemecahan Masalah Subjek Visual 2

Hasil tes tertulis yang telah dilakukan, subjek visual mampu manuliskan semua hal yang diketahui pada soal dengan lengkap, menuliskan rencana penyelesaian dengan runtut, melaksanakan rencana yang telah dibuat dengan benar dan menuliskan kesimpulan dari hasil pemecahan masalah yang telah dilakukan. Selain dari tes tertulis 
berikut cuplikan wawancara dari salah satu subjek visual Adis devi triani yang disingkat dengan $\mathrm{AD}$

Peneliti : "apa yang diketahui dan ditanyakan dari soal tersebu ?"

AD : "harga beli Rp. 250.000, biaya PengirimanR p. 50.000 dan untungnya $15 \%$. yang ditanyakan harga penjualanya kak" (menjawab dengan suara jelas)"

Peneliti : "langkah apa yang perlu dilakukan untuk menyelesaiakan masalah tersebut?"

AD : "mencari harga jual dan harga beli."

Peneliti : "bagaimana proses penyelesaian masalah yang kamu lakukan dek"

AD : "harga beli dari harga ditambah biaya pengiriman dan harga jual dari harga pembelian ditambah untung"

Peneliti : "sebelum mengerjakan nomor 2 apakah kamu cek kembali dek ?" AD : "iya kak, saya cek lagi"

Berdasarkan cuplikan hasil tes tertulis dan cuplikan wawancara, subjek visual melakukan tahap memahami, merencanakan, melaksanakan dan memeriksa kembali. Selanjutnya hasil pemecahan masalah yang dilakukan subjek audiotorialal adalah sebagai berikut.

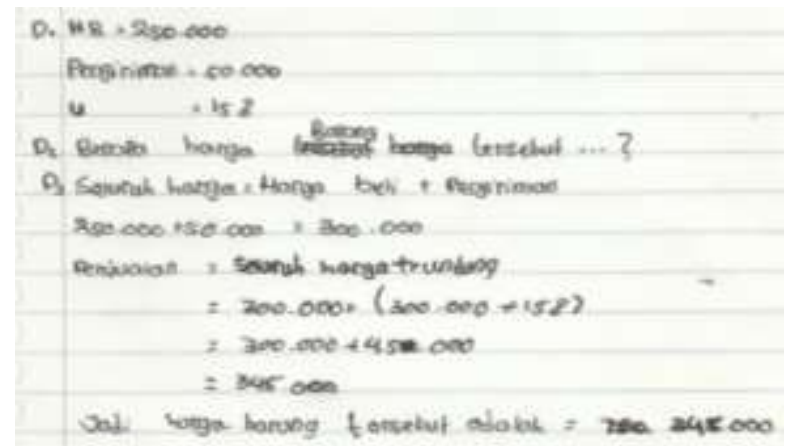

Gambar 3. Hasil Pemecahan Masalah Subjek Audiotorial 1

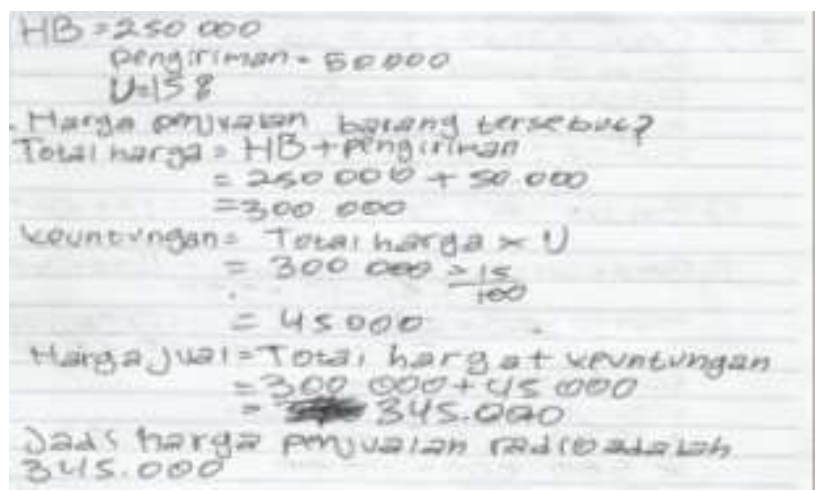

Gambar 4. Hasil Pemecahan Masalah Subjek Audiotorial 2

Hasil tes tertulis yang telah dilakukan, subjek audiotorial manuliskan semua hal yang diketahui pada soal dengan singkatan, menuliskan rencana penyelesaian dengan runtut, melaksanakan rencana yang telah dibuat dengan benar dan menuliskan kesimpulan dari hasil pemecahan masalah yang telah dilakukan, berikut cuplikan wawancara dari salah satu subjek audiotorial Dava dwi putra yang disingkat dengan DD. 


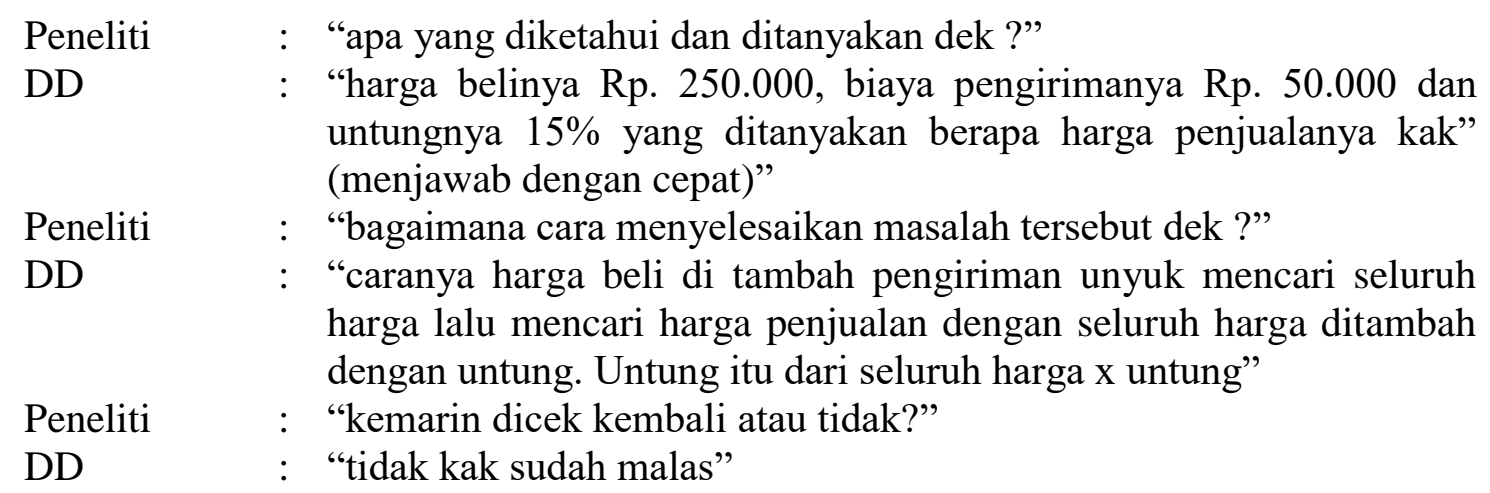

Berdasarkan cuplikan hasil tes tertulis dan wawancara, subjek audiotorial dapat memahami masalah, merencanakan penyelesaian, melaksanakan rencana namun tidak melakukan tahap memeriksa kembali. Sedangkan pada hasil pemecahan masalah siswa kinestetik sebagai berikut.

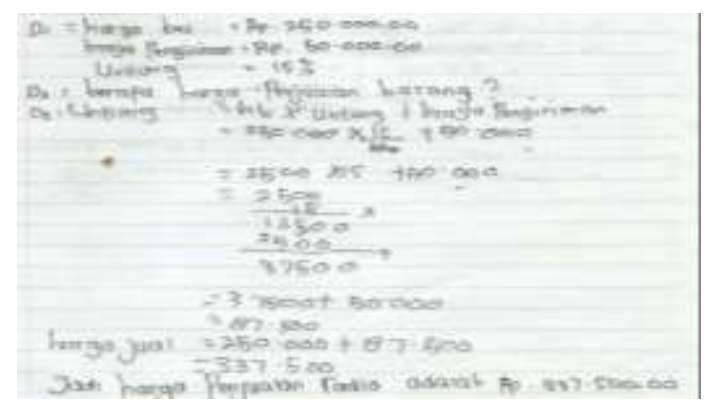

Gambar 5. Hasil Pemecahan Masalah Subjek Kinestetik 1

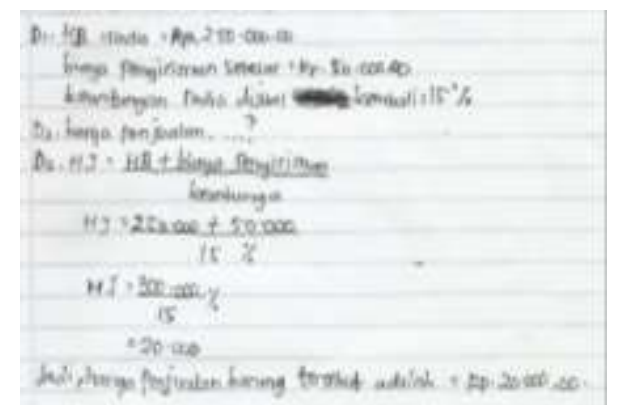

Gambar 6. Hasil Pemecahan Masalah Subjek Kinestetik 2

Berdasarkan hasil tes tertulis yang dilakukan subjek kinestetik dapat memahami masalah dengan baik namun subjek kinestetik belum mampu melakukan tahap merencanakan penyelesaian, tahap melaksanakan rencana sehingga hasil yang diperoleh kurang tepat. berikut cuplikan wawancara dari salah satu subjek kinestetik Sukma sintia rahayu yang disingkat SS

Peneliti : "Apa yang diketahui dan ditanyakan dari soal tersebut dek ?"

SS : "harga beli Rp.200.000, biaya pengiriman Rp. 50.000 dan untungnya $15 \%$, yang ditanyakan harga penjualan barang kak (SK-1 menjawab dengan suara pelan)"

Peneliti : "lalu cara penyelesaiannya?"

SS : "mencari untung dengan cara harga beli dikali dengan untung dan harga jual dengan cara harga beli x untung + pengiriman"

Peneliti : "kemarin kamu cek kembali nggak dek?" 
SS : "tidak kak karena saya gugup"

Subjek kinestetik dapat memahami masalah namun rencana penyelesaian masalah yang dibuat kurang tepat sehingga hasil yang diperoleh menjadi salah, subjek kinestetik juga tidak melakukan tahap memeriksa kembali karena subjek kinestetik merasa gugup.

\section{PEMBAHASAN}

Berdasarkan tes pemecahan masalah serta wawancara yang telah dilakukan siswa visual mampu melakukan 4 tahap polya, subjek visual dapat memahami masalah dengan baik. Ketika diminta memahami masalah subjek visual membaca dalam hati dan cepat. Subjek visual mampu menyusun rencana penyelesaian dengan baik dan runtut. Tahap melaksanakan rencana, siswa visual dapat melakukan rencana yang telah dibuat dengan baik, sehingga dapat memperoleh hasil yang benar, begitu pula pada tahap mengecek kembali subjek visual menghitung kembali jawaban yang telah dibuat, Deporter dalam Santoso (2016) mengungkapkan salah satu ciri-ciri siswa visual adalah siswa yang teliti sehingga memungkinkan siswa visual untuk mengecek tahap pemecahan masalah yang telah dibuat.

Siswa audiotorialal mampu melaksanakan tiga tahap polya. Saat memahami masalah subjek audiotorial membaca soal dengan suara keras dan lancar, menuliskan apa yang diketahui dan ditanyakan dengan singkatan. Wahyuni (2017) mengungkapkan bahwa ciri-ciri gaya belajar audiotorialal adalah senang membaca keras. Subjek audiotorial melakukan penyelesaian dengan lebih singkat, subjek audiotorial terkadang membaca sekilas sambil menggerakkan bibirnya. Sundayana (2016) mengungkapakan gaya belajar audiotorialal memiliki salah satu ciri-ciri yaitu menggerakkan bibir dan mengucapkan tulisan dibuku ketika membaca. Subjek audiotorial tidak melakukan tahap memeriksa kembali dikarenakan jenuh, malas dan lebih memilih berbicara dengan temanya.

Siswa kinestetik dalam memecahkan masalah aritmetika sosial dengan tahap polya hanya mampu melakukan tahap memahami masalah. Ketika diminta untuk memahami masalah siswa kinestetik membaca dalam hati dengan menunjuk soal yang dibaca. Siswa kinestetik belum mampu membuat rencana penyelesaian melaksanakan rencana. Pada tahap memeriksa kembali siswa kinestetik tidak melaksanakan tahap tersebut karena merasa gugup dan waktunya tidak mencukupi. Seperti yang diungkapkan In'am (2014) yang menyatakan bahwa mayoritas siswa tidak melakukan langkah melihat kembali dengan alasan tidak cukup waktu untuk melakukan tahap memeriksa kembali. Untuk mengetahui kebasahan temuan maka dilakukan triangulasi dengan hasil sebagai berikut.

Tabel 1. Hasil Triangulasi Sumber

\begin{tabular}{clc}
\hline \multicolumn{1}{c}{ Subjek } & \multicolumn{1}{c}{ Hasil } & Keterangan \\
\hline Subjek visual 1 & memahami masalah & $\sqrt{ }$ \\
& merencanakan penyelesaian & $\sqrt{ }$ \\
& melaksanakan rencana & $\sqrt{ }$ \\
Subjek visual 2 & memeriksa kembali & $\sqrt{ }$ \\
& memahami masalah & $\sqrt{ }$ \\
& merencanakan penyelesaian & $\sqrt{ }$ \\
Sunjek audiotorial 1 & melaksanakan rencana & $\sqrt{ }$ \\
& memeriksa kembali & $\sqrt{ }$ \\
& memami masalah & $\sqrt{ }$
\end{tabular}




\begin{tabular}{lll} 
& merencanakan penyelesaian & $\sqrt{ }$ \\
& melaksanakan rencana & $\sqrt{ }$ \\
memeriksa kembali & - & $\sqrt{ }$ \\
Subjek audiotorial 2 & memahami masalah & $\sqrt{ }$ \\
& merencanakan penyelesaian & $\sqrt{ }$ \\
& melaksanakan rencana & - \\
Subjek kinestetik 1 & memeriksa kembali & $\sqrt{ }$ \\
& merencanakan penyelesaian & - \\
Subjek kinestetik 2 & melaksanakan rencana & - \\
& memahami masalah & - \\
& merencanakan penyelesaian & $\sqrt{ }$ \\
& melaksanakan rencana & - \\
& memeriksa kembali & - \\
\hline
\end{tabular}

\section{SIMPULAN DAN SARAN}

Berdasarkan hasil dan pembahasan yang telah dikemukakan sebelumnya maka dapat disimpulkan bahwa, Siswa visual mampu memecahkan masalah aritmetika sosial dengan 4 tahap polya dengan baik. Membaca dan memahami masalah dengan cepat, dapat menyusun dan melaksanakan rencana secara benar dengan tulisan tangan yang bagus, melakukan tahap memeriksa kembali jawaban yang telah dibuat dan selalu menjawab pertanyaan dengan tepat.

Siswa audiotorial dapat memecahkan masalah aritmetika sosial dengan 3 tahap polya. Membaca soal dengan suara keras, menyusun dan melaksanakan rencana dengan singkatan, ketika merasa bingung subjek audiotorialal sesekali terlihat membaca soal tanpa suara dan hanya menggerakkan kedua bola matanya, subjek tidak memeriksa kembali jawabanya karena merasa jenuh.

Siswa kinestetik hanya dapat melakukan tahap memeriksa kembali masalah dengan membaca dalam hati sambil menunjuk soal yang sedang dibaca. Subjek belum bisa menuliskan rencana penyelesaian dengan benar, hal tersebut berpengaruh pada tahap melaksanakan rencana sehingga hasil yang diperoleh tidak tepat. Saat diwawancarai subjek sering menjawab dengan lama dan sering memainkan bolpoin yang dipegang, subjek juga tidak melakukan tahap memeriksa kembali karena merasa gugup.

Banyak kekurangan dalam penelitian yang telah dilakukan, dengan demkian peneliti mengharapkan untuk penelitian selanjutnya mengkaji lebih lanjut mengenai pemecahan masalah yang ditinjau dari sisi lain, misalnya dari gaya kognitif yang berkaitan erat dengan siswa untuk memecahkan suatu masalah pada soal. Selain itu peneliti selanjutnya dapat melakukan penelitian lanjut tentang pemeblajaran dan strategi pemecahan masalah dari materi matematika lainya.

\section{DAFTAR RUJUKAN}

Arfanuddin, S. \& Sutji. (2016). Profil Pemecahan Masalah Matematika Siswa Smk Kelas X Ditinjau Dari Gaya Kognitif. Jurnal Pendidikan Matematika. 5,3, 433445. 
Aziz, F. A. (2017). Quality Service Education Of Course And Training Institute (Lkp) Dian Gitaya. http://eprints.uny.ac.id.

Damanik, J. (2015). Gaya Belajar Mahasiswa yang Bekerja: Penelitian di STIKIP Purnama Jakarta. JDP, 8,1, 25-34.

Gunawan, I. (2015). Metode Penelitian Kualitatif Teori dan Praktik, Jakarta: Bumi Angkasa.

In'am, A. (2014). The Implementation of the Polya Method in Solving Euclidean Geometry Problems. International Education Studies, 7,7, 149-158.

Indrawati, R. (2017). Profil Pemecahan Masalah Matematika Ditinjau dari Gaya Belajar. Jurnal Program Studi Pendidikan Matematika, 3,2, 91-101.

Junarti, dkk. (2018). The Analysis Of Heuristik Desicion Making In Abstract Algebra Proofing. IKIP PGRI BOJONEGORO: PPS UNNES 1-8.

Mahardiningrum, S. A \& Novita, R. (2018). Profil Pemecahan Masalah Matematika Siswa SMP Pangudi Luhur Salatiga Ditinjau Dari Berpikir Kritis. Jurnal Musharafa, 7,1, 75-84.

Musridik, M. E, Nur \& Hendra. (2015). Kemampuan Berpikir Kreatif Dalam Memecahkan Masalah Matematika Open-Ended Ditinjau Dari Tingkat Kemampuan Matematika Pada Siswa Sekolah Dasar. Jurnal Pedagogia, 1,1, 2334.

Prabowo, A. Hariyanto. (2013). Analisis Pemanfaatan Buku Elektronik (E-Book) Oleh Pemustaka Di Perpustakaan Sma Negeri 1 Semarang. Jurnal Ilmu Perpustakaan, 2,2, 1-9.

Restami, Suma \& Pujani, (2013). Pengaruh Model Pembelajaran POE (Predict Observe - Explaint) Terhadap Pemahaman Konsep Fisika dan Sikap Ilmiah Ditinjau Dari Gaya Belajar Siswa. Ejournal Program Pascasarjana, 3, 1-11.

Safrisnti, S. D. (2017). Pengaruh Gaya Belajar Visual, Audiotorial, Kinestetik Terhadap Hasil Belajar Siswa Kelas X IPS Program Unggulan di Man 1 Kota Malang. Tesis tidak diterbitkan. Malang: Fakultas Ilmu Tarbiyah Dan Keguruan Universitas Islam Negri Maulana Malik Ibrahim Malang

Santoso, S. E. (2016). Analisis Kemampuan Pemecahan Masalah Berdasarkan Gaya Belajar Melalui Pembelajaran Problem Based Learning. Tesis Tidak Dipublikasikan. Semarang: MIPA UNES

Sundayana, R. (2016). Kaitan Antara Gaya Belajar, Kemandirian Belajar, dan Kemampuan Pemecahan Masalah Siswa SMP Dalam Pembelajaran Matematika. Jurnal Pendidikan Matematika, 5,2, 75-85.

Utami, A. D. Sa'dijah, C. Subanji, \& Irawati. S. (2018). Six Levels of Indonesian Primary School Student's Mental Model In Comprehending The Concept Of Integer. International Journal of Instruction, 11,4, 29 - 44.

Wahyuni, Y. (2017). Identifikasi Gaya Belajar (Visual, Audiotorialal, Kinestetik) Mahasiswa Pendidikan Matematika Universitas Bung Hatta. Jurnal Penelitian dan Pendidikan Matematika, 10,3, 128-132.

Widodo, S. A. (2013). Analisis Kesalahan Dakam Pemecahan Masalah Divergensi Tipe Pembuktian Pada Mahasiswa Matematika. Jurnal Pendidikan dan Pengajaran, 46,2, 107-113.

Zaif, Sunardi \& Diah. (2013). Penerapan Pembelajaran Pemecahan Masalah Model Polya untuk Menyelesaiakn Soal - Soal Pemecahan Masalah pada Siswa Kelas IX 1 SMP Negeri 1 Jember Semester Ganjil Tahun Ajaran 2012/2013, 2,2, 119 13 . 